\title{
KONSUMSI ENERGI LISTRIK TERHADAP PERUBAHAN KECEPATAN MOTOR INDUKSI TIGA PHASA
}

\author{
Atmam $^{1}$, Elvira Zondra ${ }^{2}$, Hazra Yuvendius ${ }^{3}$ \\ ${ }_{1,2,3}$ Program Studi Teknik Elektro, Fakultas Teknik, Universitas Lancang Kuning \\ Jl. Yos Sudarso km. 8 Rumbai, Pekanbaru, Telp. (0761) 52324 \\ Email : atmam@unilak.ac.id, elviraz@unilak.ac.id,hazra_yuvendius@unilak.ac.id
}

\begin{abstract}
ABSTRAK
Motor induksi umumnya memiliki konstruksi sederhana, mudah dioperasikan, relatif lebih murah dalam perawatannya sehingga banyak digunakan di industri dan rumah tangga. Mesin listrik berupa motor induksi dilihat dari sumber tegangan salah satunya adalah jenis motor induksi tiga phasa. Motor induksi tiga phasa sering digunakan sebagai penggerak peralatan dengan kecepatan penuh atau kecepatan relatif konstan. Kecepatan motor induksi tiga phasa umumnya dapat dikendalikan yang salah satunya dengan pengaturan tegangan. Pengaturan atau pengendalian tegangan variabel pada motor induksi tiga phasa untuk memperoleh kecepatan yang berubah, dapat diperoleh dengan menggunakan ac voltage regulator tiga phasa. Perubahan sumber tegangan masukan yang variabel pada motor induksi tiga phasa akan mempengaruhi parameter motor induksi tiga phasa termasuk juga konsumsi atau penggunaan energi listrik. Dari hasil penelitian ini diperoleh konsumsi energi listrik motor induksi tiga phasa hubungan bintang tanpa beban dengan kecepatan $3000 \mathrm{rpm}$ lebih tinggi sebesar 0,079 kWh (48\%) atau Rp. 51,376 selama satu jam dibanding dengan kecepatan $2570 \mathrm{rpm}$, motor induksi tiga phasa hubungan bintang berbeban dengan kecepatan 2570 konsumsi energi listriknya lebih tinggi sebesar 0,124 kWh (22\%) atau Rp. 167,648 dibanding kecepatan $3000 \mathrm{rpm}$, konsumsi energi listrik motor induksi tiga phasa hubungan delta tanpa beban dengan kecepatan $2570 \mathrm{rpm}$ lebih tinggi sebesar 0,065 $\mathrm{kWh}(23 \%)$ atau Rp. 87,88 dibanding kecepatan $3000 \mathrm{rpm}$ dan motor induksi tiga phasa hubungan delta berbeban dengan kecepatan 2570 konsumsi energi listriknya lebih tinggi sebesar 0,551 kWh (56\%) atau Rp. 744,952 dibandingkan kecepatan $300 \mathrm{rpm}$.
\end{abstract}

Kata Kunci: Motor induksi tiga phasa, ac voltage regulator, energi listrik

\begin{abstract}
Induction motors generally have a simple construction, easy to operate, relatively cheaper in maintenance so it is widely used in industry and households. Electric machines in the form of induction motors can be seen from the voltage source, one of which is a type of three-phase induction motor. Three-phase induction motor is often used as a drive of equipment with full speed or relatively constant speed. The speed of a three-phase induction motor can generally be controlled, one of which is by regulating the voltage. Adjustment or control of variable voltage on a three-phase induction motor to obtain a changing speed, can be obtained by using a three-phase ac voltage regulator. Changes in the variable input voltage source on a three-phase induction motor will affect the parameters of a three-phase induction motor including the consumption or use of electrical energy. From the results of this study, the electrical energy consumption of three phase induction motors of stars without load with a speed of $3000 \mathrm{rpm}$ was higher by $0.079 \mathrm{kWh}(48 \%)$ or Rp. 51,376 for an hour compared to the speed of $2570 \mathrm{rpm}$, the three-phase induction motor with starloaded connections with a speed of 2570 has higher electrical energy consumption of $0.124 \mathrm{kWh}(22 \%)$ or $R$ p. 167,648 compared to the speed of $3000 \mathrm{rpm}$, the electrical energy consumption of a three-phase induction motor without delta load with a speed of $2570 \mathrm{rpm}$ is higher by $0.065 \mathrm{kWh}(23 \%)$ or Rp. 87.88 compared to the speed of 3000 rpm and a three-phase induction motor with a delta load with a speed of 2570 the electricity consumption is higher by $0.551 \mathrm{kWh}(56 \%)$ or Rp. 744,952 compared to the speed of $300 \mathrm{rpm}$.
\end{abstract}

Keywords: Three phase induction motor, AC voltage regulator, electrical energy

\section{PENDAHULUAN}

Motor induksi umumnya memiliki konstruksi sederhana, mudah dioperasikan, relatif lebih murah dalam perawatannya sehingga banyak digunakan di industri dan rumah tangga. Diperkirakan lebih dari
$50 \%$ energi listrik dunia yang dihasilkan dikonsumsi oleh mesin listrik [1].

Mesin listrik yang berupa motor induksi dilihat dari sumber tegangan yang diberikan salah satunya adalah jenis motor induksi tiga phasa. Motor induksi tiga phasa sering digunakan sebagai 
penggerak peralatan dengan kecepatan penuh atau kecepatan relatif konstan. Konsumsi daya pada motor induksi dengan kecepatan konstan lebih besar dan hal tersebut dapat menyebabkan pemborosan energi listrik. Selanjutnya [2] melakukan percobaan apabila terjadi perubahan beban, akan terjadi perubahan kecepatan, untuk itu kecepatan harus dikendalikan.

Kecepatan motor induksi tiga phasa umumnya dapat dikendalikan yang salah satunya dengan pengaturan tegangan. Pengaturan atau pengendalian tegangan variabel yang diberikan pada motor induksi tiga phasa untuk memperoleh kecepatan yang variabel dapat diperoleh dengan menggunakan ac voltage regulator tiga phasa. Perubahan sumber tegangan masukan yang variabel pada motor induksi tiga phasa akan mempengaruhi parameter motor induksi tiga phasa termasuk juga konsumsi atau penggunaan energi listrik.

Dari uraian di atas, maka untuk melihat konsumsi atau penggunaan energi listrik terhadap perubahan kecepatan motor induksi tiga phasa maka perlu dilakukan penelitian. Pada penelitian ini, untuk menganalisa konsumsi atau penggunaan energi listrik pada motor induksi tiga phasa yaitu motor induksi dalam hubungan bintang dan delta saat tanpa beban dan berbeban menggunakan ac voltage regulator tiga phasa sebagai pengaturan tegangan yang diberikan kepada motor induksi tiga phasa.

\section{METODE PENELITIAN}

Metode penelitian yang digunakan dalam penelitian ini adalah :

\section{Metode pengumpulan data}

Metode yang digunakan pada proses pengumpulan data yaitu metode eksperiment yaitu dari objek yang diteliti yaitu motor induksi tiga phasa $1 \mathrm{HP}, 220 / 380$ Volt, $50 \mathrm{~Hz}, 3000 \mathrm{rpm}$ untuk mendapatkan data-data seperti kecepatan, tegangan, arus, daya, cos phi dan energi listrik motor induksi tiga phasa hubungan bintang dan delta

\section{Metode Pengolahan data}

Dari data yang diperoleh dari percobaan dan pengukuran motor induksi tiga phasa hubungan bintang dan delta menggunakan $A C$ Voltage regulator tiga phasa, data-data tersebut digunakan untuk menghitung penggunaan energi listrik.

\section{Analisis data}

Dari data yang telah diolah selanjutnya dilakukan analisa data untuk mendapat nilai daya dan energi listrik motor induksi tiga phasa hubungan bintang dan delta serta penggunaan energi listrik saat perubahan kecepatan motor induksi tiga phasa hubungan bintang dan delta tanpa beban dan berbeban dan hasilnya dibandingkan.
Umumnya motor induksi dikenal ada dua macam berdasarkan jumlah fasa yang digunakan, yaitu: motor induksi satu fasa dan motor induksi tiga fasa. Sesuai dengan namanya motor induksi satu fasa dirancang untuk beroperasi menggunakan suplai tegangan satu fasa dan motor induksi tiga fasa dengan suplai tegangan tiga fasa. Motor induksi sering digunakan sebagai penggerak pada peralatan dengan kecepatan yang relatif konstan. Hal ini disebabkan karena motor induksi satu fasa memiliki beberapa kelebihan yaitu konstruksi yang cukup sederhana, kecepatan putar yang hampir konstan terhadap perubahan beban [3]. Motor induksi (IM) banyak digunakan dalam banyak aplikasi, biaya rendah, torsi yang baik, dan tahan [4].

Beberapa cara untuk mengendalikan kecepatan putar motor induksi tersebut di antaranya dengan kendali tegangan dan frekuensi yang dikenal dengan kendali V/f konstan. Kendali V/f konstan adalah salah satu cara untuk mengendalikan kecepatan putar motor induksi dengan merubah tegangan dan frekuensi, tetapi menjaga konstan rasio keduanya. Sehingga dengan cara kendali ini, torsi yang dihasilkan dapat dijaga konstan sepanjang daerah pengaturan kecepatan. Hal yang paling umum dalam penerapan cara ini adalah dengan menggunakan perangkat yang dikenal sebagai inverter [5].

Kebutuhan akan kecepatan variabel motor induksi ac muncul dalam aplikasi industri tertentu dan ini seringkali sulit dicapai karena motor induksi memiliki kecepatan tetap. Hasil penelitian memperlihatkan bahwa untuk mencapai kontrol kecepatan motor induksi dari nol ke kecepatan nominal dengan memvariasikan frekuensi tegangan ac yang diberikan dengan menggunakan metode modulasi lebar pulsa [6].

Untuk penelitian selanjutnya [7], peneliti melakukan penelitian bahwa peralatan pada umumnya selalu beroperasi pada harga tegangan listrik nominal atau tegangan penuh misalkan 220 volt perfasa atau 380 volt tiga fasa. Pada kondisi ini apabila motor tidak berbeban penuh misalkan setengah dari beban penuhnya, maka akan terjadi pemborosan pemakaian energi listrik, terlebih lagi jika motor tidak diberi beban mekanik pada porosnya.

\section{Motor Induksi Tiga Phasa}

Motor induksi tiga phasa adalah mesin listrik yang bekerja berdasarkan adanya interaksi antara induksi elektromagnetik medan putar yang ditimbulkan oleh arus tiga phasa dan arus yang di induksikan dari rangkaian stator. Bila stator dihubungkan dengan tegangan jala-jala tiga phasa, besar fluksi pada kutub-kutub setiap phasa selalu berubah sesuai fungsi waktu dan menghasilkan fluksi total yang bergerak mengelilingi stator dalam arah radial. Motor induksi pada dasarnya terdiri dari dua 
bagian utama yaitu bagian yang berputar (rotor) dan bagian yang diam (stator).

Pada saat bagian stator diberi tegangan maka akan timbul fluks yang konstan dan berputar, fluks ini melalui celah udara memotong permukaan rotor dan batang-batang rotor yang masih dalam keadaan diam. Fluks yang berputar ini disebut medan putar dengan kecepatan sinkron maka berlaku persamaan :

$$
n_{s}=\frac{120 \times f}{P}
$$

Keterangan :

$n_{s}=$ Kecepatan medan putar stator (rpm)

$f=$ Frekuensi jala-jala $(\mathrm{Hz})$

$P=$ Jumlah kutub

Karena kecepatan relatif antara fluks yang berputar dengan batang konduktor yang diam maka batang rotor akan terinduksi suatu emf. Karena batang-batang rotor membuat rangkaian tertutup maka ada arus yang mengalir. Interaksi antara medan putar dan arus yang mengalir menimbulkan gaya dan menyebabkan rotor berputar dengan arah yang sama seperti medan putar stator, seolah-olah mengikuti medan putar tersebut. Pada kenyataannya, rotor tidak akan dapat mengikuti kecepatan medan putar. Kalau rotor dapat berputar sama seperti kecepatan medan stator maka kecepatan relatif diantara keduanya adalah nol akibatnya emf yang di induksikan adalah nol sehingga tidak ada arus yang mengalir di rotor dan tidak ada torsi yang dihasilkan. Oleh sebab itu rotor selalu berputar pada kecepatan yang lebih kecil dari stator. Hubungan kecepatan rotor dan stator dinyatakan sebagai slip dan ditulis dengan persamaan:

$$
s=\frac{\omega_{s}-\omega_{r}}{\omega_{s}}
$$

dengan $s: \operatorname{slip}$ dan $\omega_{s}, \omega_{s}:$ kecepatan putar stator, rotor.

\section{Tegangan Induksi Motor}

Gerak relatif dari fluks terhadap penghantar rotor mengimbaskan tegangan dengan frekuensi sebesar $s f$, yang disebut frekuensi rotor. Jadi, karakter secara kelistrikan suatu motor induksi mirip dengan karakter transformator tetapi dengan sifat tambahan berupa perubahan frekuensi pada bagian rotor. Oleh karena itu medan rotor dan stator satu terhadap yang lain tetap, suatu torsi konstan dihasilkan dan putaran terpelihara. Suatu motor yang apabila mempunyai putaran yang dihasilkan dari proses induksi tegangan maka motor tersebut disebut motor induksi. Karena motor jenis ini mempunyai kecepatan mekanis $n$ yang tidak sama dengan kecepatan serempak maka bisa disebut pula sebagai motor tak-serempak atau asynchronous motor.

Tegangan induksi pada motor terjadi bagian stator dan bagian rotor seperti dijelaskan berikut.

\section{Tegangan Induksi Pada Kumparan Stator}

Tegangan induksi yang dibangkitkan dalam kumparan stator dinyatakan dengan persamaan [8] :

$$
E_{s}=4,44 k_{p} k_{b} N_{s} f_{s} \Phi_{d}
$$

$\Phi_{d}$ adalah fluks magnet, $f_{s}$ frekuensi stator, $k_{p}$ faktor kisar kumparan stator (pitch factor), dan $k_{b}$ faktor distribusi kumparan stator (breath factor)

\section{Rangkaian Ekivalen Motor Induksi}

Motor induksi ini terdiri dari bagian stator dan bagian rotor. Untuk mempermudah analisis motor induksi dalam kondisi steady-state diperlukan rangkaian ekivalen yang dapat mewakili bagianbagian motor tersebut secara kelistrikan. Rangkaian ekivalen motor induksi dengan suplai tegangan sinusoidal seperti pada gambar 1 .

Gambar 1. Rangkaian ekivalen motor induksi suplai tegangan sinusoidal

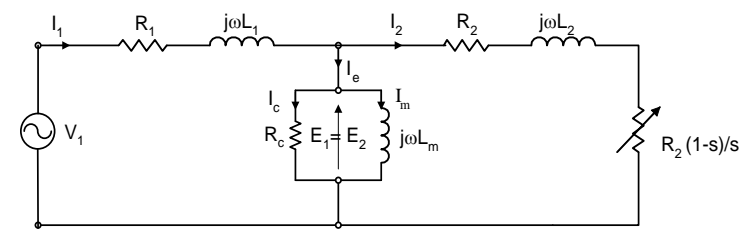

Persamaan tegangan dan arus dari rangkaian gambar 2.1. adalah :

$$
\begin{aligned}
& V_{1}=E_{1}+I_{1} R_{1}+j I_{1} \omega L_{1} \\
& E_{20}=I_{2} \frac{R_{2}}{s}+j I_{2} \omega L_{2} \\
& I_{1}=I_{e}+I_{2}=I_{m}+I_{c}+I_{2}
\end{aligned}
$$

Dengan $\mathrm{V}_{1}=$ tegangan terminal sisi stator, $\mathrm{E}_{1}=$ tegangan induksi pada kumparan stator, $I_{1}=$ arus stator, $\mathrm{I}_{2}=$ arus rotor, $\mathrm{I}_{\mathrm{m}}=$ arus magnetisasi, $\mathrm{I}_{\mathrm{c}}=$ arus untuk mengimbangi rugi besi, $\mathrm{R}_{1}=$ tahanan kumparan stator, dan $\mathrm{R}_{2}=$ tahanan kumparan rotor.

\section{Energi dan Daya Listrik}

Energi listrik merupakan sejumlah daya listrik yang digunakan atau diserap selama waktu tertentu dan energi listrik diukur dengan menggunakan alat ukur listrik disebut dengan wattjam meter atau kWh meter atau MWh meter. Satuan energi listrik antara lain : watt detik, wattjam, kilo Watt jam (kWh), Mega Watt jam (MWh). Energi listrik dapat dituliskan dengan persamaan :

$$
W=P \times t
$$

Keterangan:

$W=$ Energi Listrik $(\mathrm{Wh})$

$P=\operatorname{daya}($ Watt $)$

$t=$ waktu

Daya adalah suatu gaya yang menyebabkan sesuatu benda dapat bergerak atau jumlah kerja yang dapat dilakukan dalam satuan waktu dan diberi 
dengan satuan watt atau Joule/detik. 1 Watt sama dengan 1 Joule/detik adalah jumlah kerja yang dilakukan oleh muatan 1 Coulomb yang mengalir melalui perbedaan potensial 1 volt dalam setiap detik atau sebagai daya yang digunakan bila 1 amper arus mengalir melalui perbedaan potensial 1 Volt. Dalam ilmu mekanik untuk satuan daya biasanya menggunakan istilah horse power (hp), dimana $1 \mathrm{Hp}$ setara dengan 746 watt dan dapat dituliskan sebagai berikut :

$$
P=V \times I
$$

Keterangan:

$P=$ daya (Watt)

$V=$ tegangan $($ Volt $)$

$I=\operatorname{arus}$ (Amper)

Perhitungan daya pada motor induksi tiga phasa dapat dihitung dengan menggunakan persamaan :

$$
P=\sqrt{3} \times V \times I \times \operatorname{Cos} \varphi
$$

\section{HASIL DAN PEMBAHASAN}

Data motor induksi tiga phasa dari data name plate yang diteliti adalah sebagai berikut :

Daya Motor : $1 \mathrm{HP}(0,75 \mathrm{~kW})$

Jumlah Kutub : 2

Frekuensi $: 50 \mathrm{~Hz}$

Tegangan : $: 220 /$ Y 380 Volt

Putaran : $2800 \mathrm{rpm}$

Arus $\quad: \Delta 3,11 / \mathrm{Y} 1,80$ Amper hubungan bintang dan delta tanpa beban dan berbeban dengan kecepatan motor induksi yang berubah atau variabel dengan suplai tegangan yang diperoleh dari pengaturan tegangan input menggunakan regulator $A C$ tiga phasa. Berikut adalah model motor induksi tiga phasa yang dilakukan pada penelitian ini seperti pada gambar 1 .

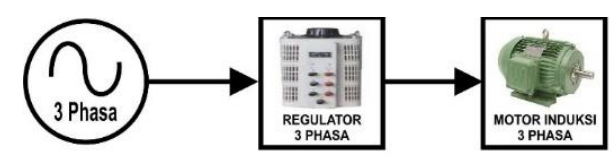

(a)

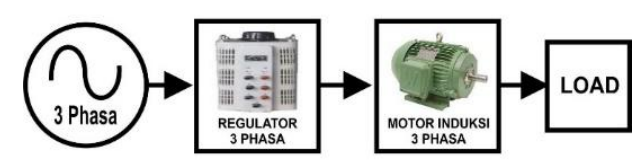

(b)

Gambar 1. Blok diagram penelitian pengoperasian motor induksi tiga phasa (a) Motor induksi tanpa beban (b)

Motor induksi berbeban

Pada proses penelitian ini dilakukan pengambilan data melalui percobaan dan pengukuran tegangan, arus, daya, faktor daya, energi listrik dan kecepatan putar rotor motor induksi tiga phasa dengan kumparan hubungan bintang tanpa beban seperti pada tabel 1. Data selanjutnya berupa hasil pengukuran motor induksi tiga phasa dengan kumparan hubungan bintang berbeban seperti pada tabel 2 .

Pada penelitian ini, pengujian motor induksi tiga phasa dilakukan dengan kumparan stator

Tabel 1. Hasil pengukuran tegangan, arus, daya, faktor daya, energi listrik dan kecepatan putar rotor motor induksi hubungan bintang tanpa beban.

\begin{tabular}{cccccccc}
\hline Tanggal & Waktu & $\begin{array}{c}\text { Kecepatan } \\
(\mathrm{rpm})\end{array}$ & $\begin{array}{c}\text { Tegangan } \\
(\text { Volt })\end{array}$ & $\begin{array}{c}\text { Arus } \\
(\text { Amper })\end{array}$ & Cos phi & $\begin{array}{c}\text { Total Daya (P) } \\
(\mathrm{kW})\end{array}$ & $\begin{array}{c}\text { Total Energi } \\
\text { Listrik (kWh) }\end{array}$ \\
\hline $13 / 04 / 2019$ & $15: 38: 50 \mathrm{~s} / \mathrm{d} 16: 38: 50$ & 3000 & 380 & 0,97 & 0,12 & 0,076 \\
\hline $14 / 04 / 2019$ & $08: 22: 49 \mathrm{~s} / \mathrm{d}$ 09:22:49 & 2570 & 50 & 0,54 & 0,81 & 0,039 & 0,041 \\
\hline
\end{tabular}

Tabel 2. Hasil pengukuran tegangan, arus, daya, faktor daya, energi listrik dan kecepatan putar rotor motor induksi hubungan bintang berbeban.

\begin{tabular}{cccccccc}
\hline Tanggal & Waktu & $\begin{array}{c}\text { Kecepatan } \\
(\mathrm{rpm})\end{array}$ & $\begin{array}{c}\text { Tegangan } \\
(\text { Volt })\end{array}$ & $\begin{array}{c}\text { Arus } \\
(\text { Amper })\end{array}$ & Cos phi & $\begin{array}{c}\text { Total Daya (P) } \\
(\mathrm{kW})\end{array}$ & $\begin{array}{c}\text { Total Energi } \\
\text { Listrik (kWh) }\end{array}$ \\
\hline 25/06/2019 & $09: 06: 19 \mathrm{~s} / \mathrm{d} 10: 06: 19$ & 3000 & 380 & 0,90 & 0,74 & 0,403 & 0,423 \\
\hline 25/06/2019 & $10: 27: 08 \mathrm{~s} / \mathrm{d} 11: 27: 08$ & 2570 & 70 & 0,58 & 0,97 & 0,049 \\
\hline
\end{tabular}

Pengambilan data berikutnya melalui percobaan dan pengukuran tegangan, arus, daya, faktor daya, energi listrik dan kecepatan putar rotor motor induksi tiga phasa dengan kumparan hubungan delta tanpa tanpa beban seperti pada tabel 3 .
Hasil pengukuran motor induksi tiga phasa dengan kumparan hubungan delta berbeban diperlihatkan pada tabel 4 . 
Tabel 3. Hasil pengukuran tegangan, arus, daya, faktor daya, energi listrik dan kecepatan putar rotor motor induksi hubungan delta tanpa beban.

\begin{tabular}{cccccccc}
\hline Tanggal & Waktu & $\begin{array}{c}\text { Kecepatan } \\
(\mathrm{rpm})\end{array}$ & $\begin{array}{c}\text { Tegangan } \\
(\text { Volt })\end{array}$ & $\begin{array}{c}\text { Arus } \\
(\text { Amper })\end{array}$ & Cos phi & $\begin{array}{c}\text { Total Daya (P) } \\
(\mathrm{kW})\end{array}$ & $\begin{array}{c}\text { Total Energi } \\
\text { Listrik }(\mathrm{kWh})\end{array}$ \\
\hline $14 / 04 / 2019$ & $11: 33: 56 \mathrm{~s} / \mathrm{d} 12: 33: 56$ & 3000 & 216,167 & 1,563 & 0,12 & 0,072 & 0,206 \\
\hline $14 / 04 / 2019$ & $12: 57: 36 \mathrm{~s} / \mathrm{d} 13: 57: 36$ & 2570 & 29,7 & 0,866 & 0,75 & 0,038 & 0,271 \\
\hline
\end{tabular}

Tabel 4. Hasil pengukuran tegangan, arus, daya, faktor daya, energi listrik dan kecepatan putar rotor motor induksi hubungan delta berbeban.

\begin{tabular}{cccccccc}
\hline Tanggal & Waktu & $\begin{array}{c}\text { Kecepatan } \\
(\mathrm{rpm})\end{array}$ & $\begin{array}{c}\text { Tegangan } \\
(\text { Volt })\end{array}$ & $\begin{array}{c}\text { Arus } \\
(\text { Amper })\end{array}$ & Cos phi & $\begin{array}{c}\text { Total Daya } \\
(\mathrm{P}) \\
(\mathrm{kW})\end{array}$ & $\begin{array}{c}\text { Total Energi } \\
\text { Listrik }(\mathrm{kWh})\end{array}$ \\
\hline $26 / 06 / 2019$ & $09: 47: 08 \mathrm{~s} / \mathrm{d} 10: 47: 08$ & 3000 & 220 & 1,58 & 0,71 & 0,397 & 0,428 \\
\hline $26 / 06 / 2019$ & $12: 31: 36 \mathrm{~s} / \mathrm{d} 13: 31: 36$ & 2570 & 40 & 1,448 & 0,78 & 0,024 & 0,979 \\
\hline
\end{tabular}

1. Daya dan energi listrik motor induksi tiga phasa hubungan bintang tanpa beban.

Daya dan pemakaian energi listrik motor induksi tiga phasa hubungan bintang tanpa beban dengan kecepatan 3000 rpm dapat dihitung dengan menggunakan data pada tabel 1 dan hasilnya sebagai berikut :

$$
P=\sqrt{3} \times V \times I \times \operatorname{Cos} \varphi=0,076 \mathrm{~kW}
$$

Pemakaian energi listrik selama 1 (satu) jam sebagai berikut :

$$
W=0,076 k W \times 1 j a m=0,076 k W h
$$

Terjadi perbedaan hasil perhitungan energi listrik yang tidak begitu jauh yaitu sebesar $0,003 \mathrm{kWh}$ bila melihat hasil pengukuran atau data pada tabel 1. Hasil pengukuran daya motor induksi tiga phasa hubungan bintang tanpa beban dengan kecepatan $3000 \mathrm{rpm}$ selama 1 jam dapat diperoleh bentuk grafik daya seperti pada gambar 2.

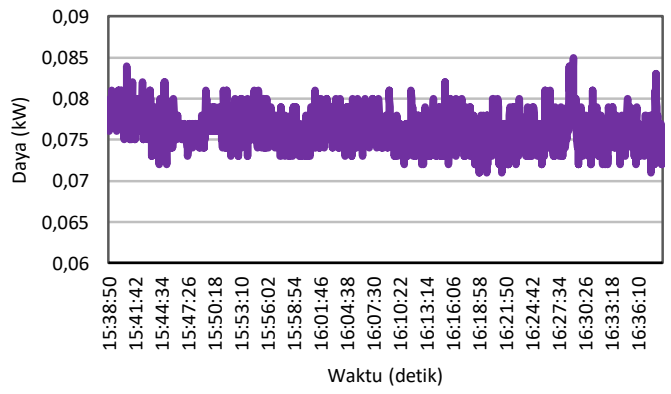

Gambar 2. Grafik daya motor induksi tiga phasa hubungan bintang dengan kecepatan 3000 rpm tanpa beban

Dari Gambar 2, motor induksi tiga phasa dioperasikan selama 1 (satu) jam dengan kecepatan $3000 \mathrm{rpm}$ dan daya yang terjadi berfluktuatif yang disebabkan oleh perubahan tegangan input yang diberikan pada motor induksi tiga phasa hubungan bintang tanpa beban. Hubungan antara pemakaian energi listrik dari motor induksi tiga phasa hubungan bintang tanpa beban pada kecepatan $3000 \mathrm{rpm}$ seperti pada gambar 3. Hal ini dimulai dari rentang waktu startingnya motor induksi tiga phasa, maka pemakaian energi listrik terus meningkat dimana pada rentang waktu 1 (satu) jam konsumsi energi listrik sebesar 0,079 kWh.

Daya dan pemakaian energi listrik motor induksi tiga phasa hubungan bintang tanpa beban dengan kecepatan 2570 rpm dapat dihitung dengan menggunakan data pada tabel 1 dan hasilnya sebagai berikut :

$$
P=\sqrt{3} \times V \times I \times \operatorname{Cos} \varphi=0,037 k W
$$

Selisih hasil perhitungan daya yaitu sebesar $0,002 \mathrm{~kW}$ bila melihat hasil pengukuran atau data pada tabel 1 . Pemakaian energi listrik selama 1 (satu) jam sebagai berikut :

$$
W=0,037 k W \times 1 j a m=0,037 k W h
$$

Terjadi perbedaan hasil perhitungan energi listrik yang tidak begitu jauh yaitu sebesar $0,004 \mathrm{kWh}$ bila melihat hasil pengukuran atau data pada tabel 1. Hasil pengukuran daya motor induksi tiga phasa hubungan bintang tanpa beban berikutnya dilakukan dengan mengatur kecepatan motor induksi tiga phasa tanpda beban dengan kecepatan 2570 rpm selama 1 jam dapat diperoleh bentuk grafik daya seperti pada gambar 4.

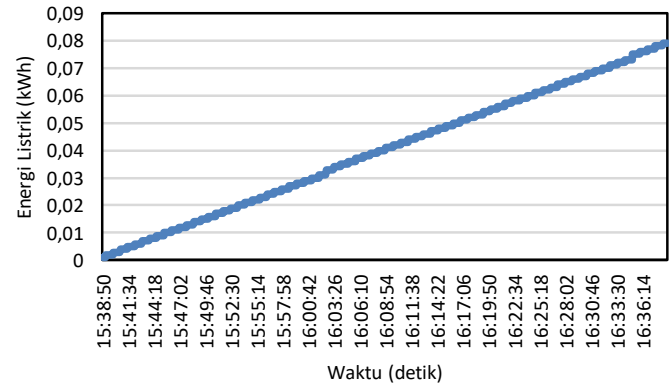

Gambar 3. Grafik pemakaian energi listrik pada motor induksi tiga phasa hubungan phasa hubungan bintang dengan kecepatan 3000 rpm tanpa beban 


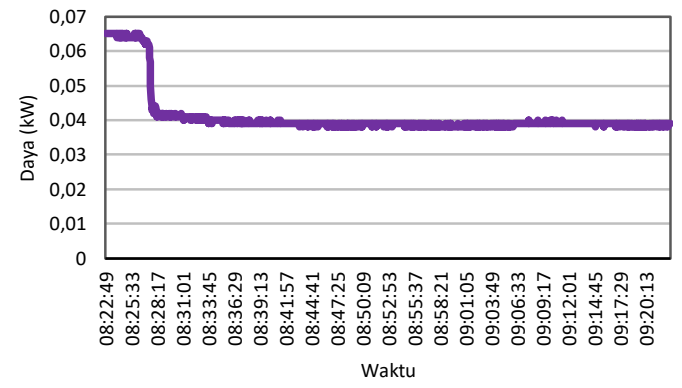

Gambar 4. Grafik daya motor induksi tiga phasa hubungan bintang dengan kecepatan 2570 rpm tanpa beban

Selanjutnya hubungan antara pemakaian energi listrik dari motor induksi tiga phasa hubungan bintang tanpa beban pada kecepatan 2570 rpm seperti pada gambar 5 dengan pemakaian energi listrik terus meningkat selama rentang waktu 1 (satu) jam dimana konsumsi energi listrik sebesar 0,041 kWh.

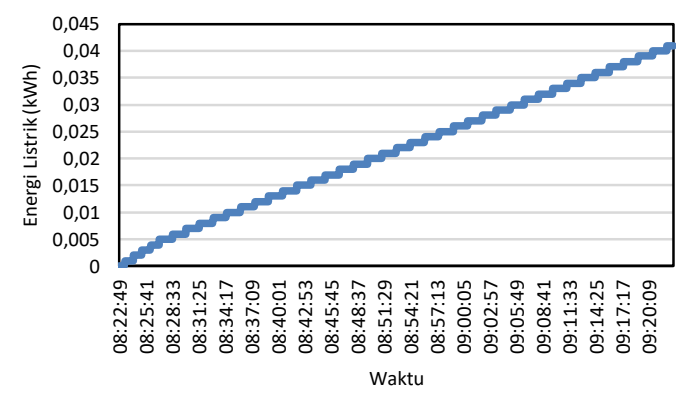

Gambar 5. Grafik pemakaian energi listrik pada motor induksi tiga phasa hubungan bintang dengan kecepatan 2570 rpm tanpa beban

Bentuk grafik perbandingan penggunaan energi listrik motor induksi tiga phasa hubungan bintang tanpa beban dengan perubahan kecepatan seperti pada gambar 6.

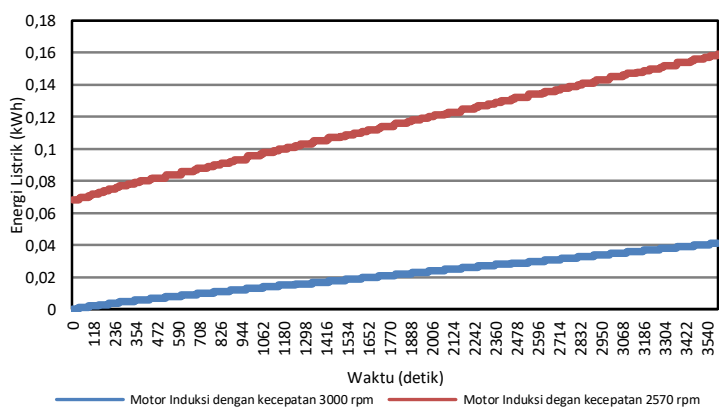

Gambar 6. Grafik perbandingan pemakaian energi listrik pada motor induksi tiga phasa hubungan bintang tanpa beban dengan perubahan kecepatan
Dari gambar 6 terlihat bahwa penggunaan energi listrik motor induksi tiga phasa hubungan bintang tanpa beban dengan perubahan kecepatan dari awal starting sampai beroperasi dalam waktu 1 jam, penggunaan energi listrik motor induksi dengan kecepatan $3000 \mathrm{rpm}$ lebih tinggi sebesar 0,038 kWh (48\%) dibandingkan dengan kecepatan motor induksi $2570 \mathrm{rpm}$.

\section{Daya dan energi listrik motor induksi tiga phasa hubungan bintang berbeban.}

Hasil pengukuran dan perhitungan berikutnya adalah daya motor induksi tiga phasa hubungan bintang berbeban dengan kecepatan 3000 rpm selama 1 jam dan dapat diperoleh bentuk grafik daya seperti pada gambar 7 .

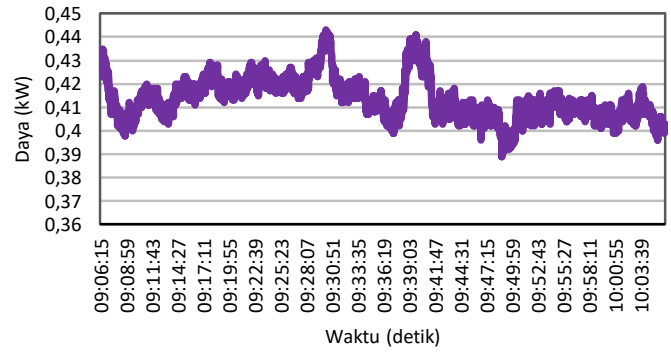

Gambar 7. Grafik daya motor induksi tiga phasa hubungan bintang dengan kecepatan 3000 rpm berbeban

Dari Gambar 7 motor induksi tiga phasa dioperasikan selama 1 (satu) jam dengan kecepatan $3000 \mathrm{rpm}$ dan daya juga berfluktuatif yang disebabkan oleh perubahan tegangan input yang diberikan pada motor induksi tiga phasa hubungan bintang berbeban. Hubungan antara pemakaian energi listrik dari motor induksi tiga phasa hubungan bintang berbeban pada kecepatan 3000 rpm seperti pada gambar 8. Hal ini dimulai dari rentang waktu startingnya motor induksi tiga phasa, maka pemakaian energi listrik terus meningkat dimana pada rentang waktu 1 (satu) jam konsumsi energi listrik sebesar $0,423 \mathrm{kWh}$.

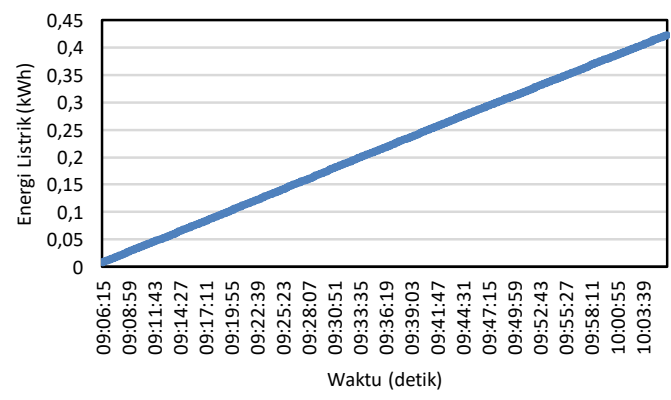

Gambar 8. Grafik pemakaian energi listrik pada motor induksi tiga phasa hubungan bintang dengan kecepatan 3000 rpm berbeban 
Hasil pengukuran daya motor induksi tiga phasa hubungan bintang berbeban berikutnya dilakukan dengan mengatur kecepatan motor induksi tiga phasa berbeban dengan kecepatan $2570 \mathrm{rpm}$ selama 1 jam, diperoleh bentuk grafik daya seperti pada gambar 9 .

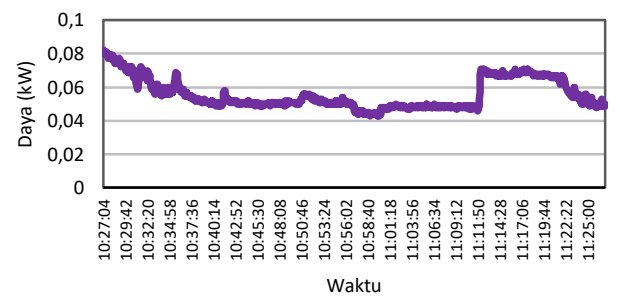

Gambar 9. Grafik daya motor induksi tiga phasa hubungan bintang dengan kecepatan 2570 rpm berbeban

Selanjutnya hubungan antara pemakaian energi listrik dari motor induksi tiga phasa hubungan bintang berbeban pada kecepatan $2570 \mathrm{rpm}$ seperti pada gambar 10 dengan pemakaian energi listrik terus meningkat selama rentang waktu 1 (satu) jam dimana konsumsi energi listrik sebesar 0,547 kWh.

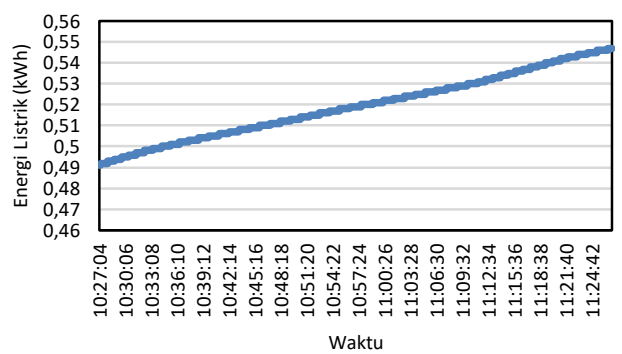

Gambar 10. Grafik pemakaian energi listrik pada motor induksi tiga phasa hubungan bintang dengan kecepatan $2570 \mathrm{rpm}$ berbeban

Bentuk grafik perbandingan penggunaan energi listrik motor induksi tiga phasa hubungan bintang berbeban dengan perubahan kecepatan seperti pada gambar 11 .

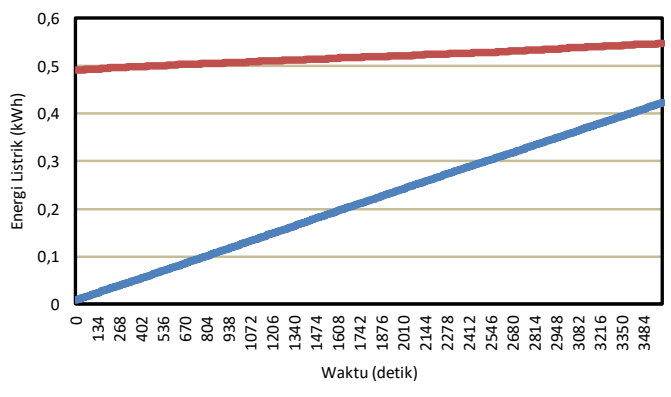

Gambar 11. Grafik perbandingan pemakaian energi listrik dengan perubahan kecepatan pada motor induksi tiga phasa hubungan bintang berbeban.
Dari gambar 11 terlihat bahwa penggunaan energi listrik motor induksi tiga phasa hubungan bintang berbeban dengan perubahan kecepatan dari awal starting sampai beroperasi dalam waktu 1 jam, penggunaan energi listrik motor induksi dengan kecepatan $2570 \mathrm{rpm}$ lebih tinggi sebesar 0,124 kWh (22\%) dibandingkan dengan kecepatan motor induksi $3000 \mathrm{rpm}$.

\section{Daya dan energi listrik motor induksi tiga phasa hubungan delta tanpa beban. \\ Daya dan pemakaian energi listrik motor} induksi tiga phasa hubungan delta tanpa beban dengan kecepatan 3000 rpm dapat dihitung dengan menggunakan data pada tabel 3 dan hasilnya sebagai berikut :

$$
P=\sqrt{3} \times V \times I \times \operatorname{Cos} \varphi=0,070 \mathrm{~kW}
$$

Pemakaian energi listrik selama 1 (satu) jam sebagai berikut :

$$
W=0,070 \mathrm{~kW} \times 1 \mathrm{jam}=0,070 \mathrm{kWh}
$$

Terjadi perbedaan hasil perhitungan energi listrik yang tidak begitu jauh yaitu sebesar $0,002 \mathrm{kWh}$ bila melihat hasil pengukuran atau data pada tabel 3 .

Bentuk grafik dari hasil pengukuran daya motor induksi tiga phasa hubungan delta tanpa beban dengan kecepatan $3000 \mathrm{rpm}$ selama 1 jam seperti pada gambar 12. Pada Gambar 12, motor induksi tiga phasa dioperasikan selama 1 (satu) jam dengan kecepatan $3000 \mathrm{rpm}$ dan daya yang terjadi berfluktuatif yang disebabkan oleh perubahan tegangan input yang diberikan pada motor induksi tiga phasa hubungan delta tanpa beban. Hubungan antara pemakaian energi listrik dari motor induksi tiga phasa hubungan delta tanpa beban pada kecepatan 3000 rpm seperti pada gambar 13. Kondisi ini dimulai dari waktu startingnya motor induksi tiga phasa, maka pemakaian energi listrik terus meningkat dimana pada rentang waktu 1 (satu) jam konsumsi energi listrik sebesar 0,206 kWh.

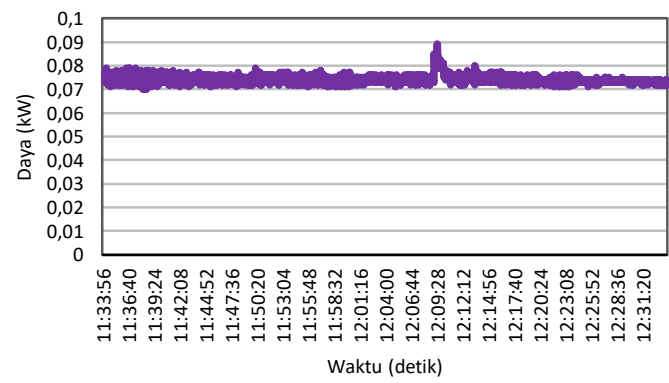

Gambar 12. Grafik daya motor induksi tiga phasa hubungan delta dengan kecepatan 3000 rpm tanpa beban

Bentuk berikutnya diperoleh dari hasil pengukuran daya motor induksi tiga phasa hubungan delta tanpa beban dengan mengatur kecepatan motor induksi tiga phasa tanpa beban dengan kecepatan 
2570 rpm selama 1 jam seperti pada gambar 14 Hubungan antara pemakaian energi listrik dari motor induksi tiga phasa hubungan delta tanpa beban pada kecepatan 2570 rpm seperti pada gambar 15 dengan pemakaian energi listrik terus meningkat selama rentang waktu 1 (satu) jam dimana konsumsi energi listrik sebesar 0,271 kWh.

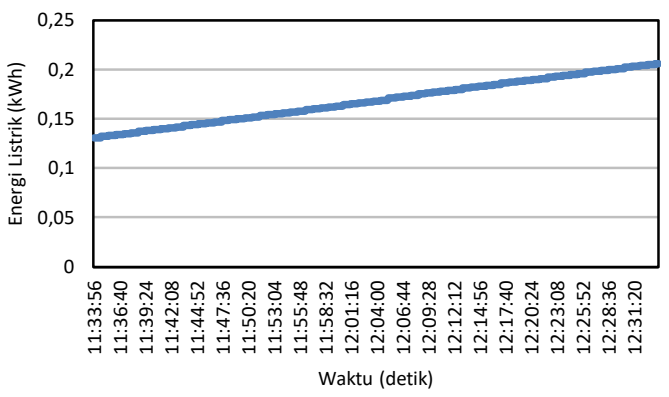

Gambar 13. Grafik pemakaian energi listrik motor induksi tiga phasa hubungan delta dengan kecepatan 3000 rpm tanpa beban

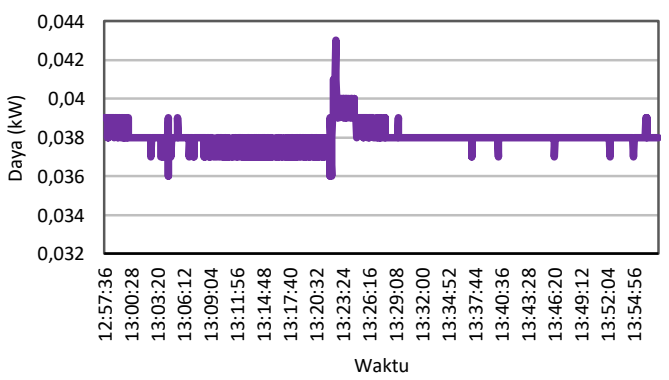

Gambar 14. Grafik daya motor induksi tiga phasa hubungan delta dengan kecepatan 2570 rpm tanpa beban

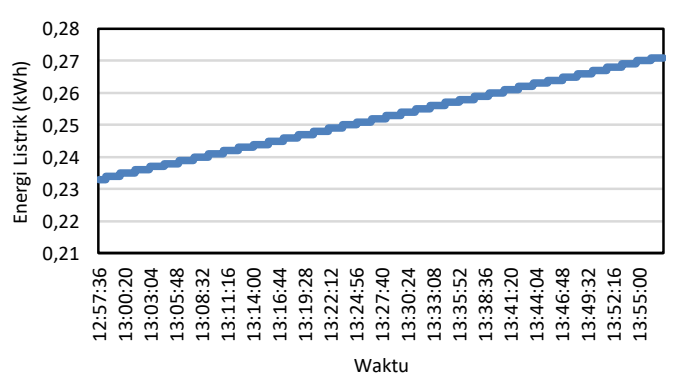

Gambar 15. Grafik pemakaian energi listrik motor induksi tiga phasa hubungan delta dengan kecepatan 2570 rpm tanpa beban

Bentuk grafik perbandingan penggunaan energi listrik motor induksi tiga phasa hubungan delta tanpa beban dengan perubahan kecepatan seperti pada gambar 16.

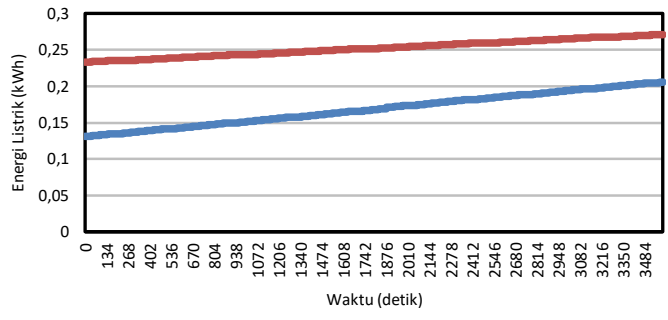

Gambar 16. Grafik perbandingan pemakaian energi listrik dengan perubahan kecepatan pada motor induksi tiga phasa hubungan delta tanpa beban.

Dari gambar 16 terlihat bahwa penggunaan energi listrik motor induksi tiga phasa hubungan delta tanpa beban dengan perubahan kecepatan dari awal starting sampai beroperasi dalam waktu 1 jam penggunaan energi listrik motor induksi dengan kecepatan $2570 \mathrm{rpm}$ lebih tinggi sebesar 0,065 kWh (23\%) dibandingkan dengan kecepatan motor induksi $3000 \mathrm{rpm}$.

\section{Daya dan energi listrik motor induksi tiga phasa hubungan delta berbeban.}

Daya dan pemakaian energi listrik motor induksi tiga phasa hubungan delta berbeban dengan kecepatan $3000 \mathrm{rpm}$ dapat dihitung dengan menggunakan data pada tabel 4 dan hasilnya sebagai berikut :

$$
P=\sqrt{3} \times V \times I \times \operatorname{Cos} \varphi=0,428 k W
$$

Pemakaian energi listrik selama 1 (satu) jam sebagai berikut :

$$
W=0,428 k W \times 1 j a m=0,429 k W h
$$

Hasil pengukuran dan perhitungan berikutnya adalah daya motor induksi tiga phasa hubungan delta berbeban dengan kecepatan $3000 \mathrm{rpm}$ dengan tegangan suplai sebesar 220 Volt selama 1 jam dan dapat diperoleh bentuk grafik daya seperti pada gambar 17.

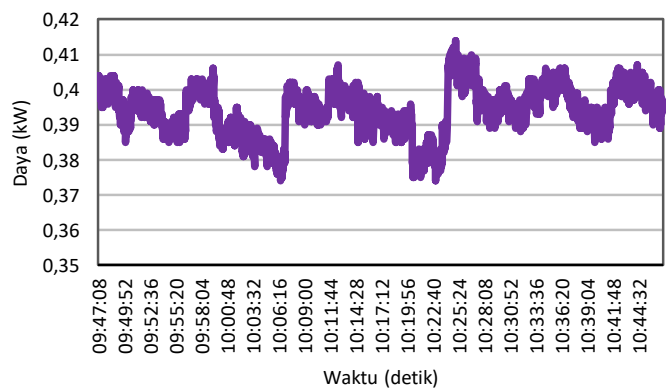

Gambar 17. Grafik daya motor induksi tiga phasa hubungan delta dengan kecepatan 3000 rpm berbeban 
Dari Gambar 17 motor induksi tiga phasa dioperasikan selama 1 (satu) jam dengan kecepatan 3000 rpm dan daya juga berfluktuatif yang disebabkan oleh perubahan tegangan input yang diberikan pada motor induksi tiga phasa hubungan delta berbeban. Hubungan antara pemakaian energi listrik dari motor induksi tiga phasa hubungan delta berbeban pada kecepatan $3000 \mathrm{rpm}$ seperti pada gambar 18. Kondisi ini juga dimulai dari rentang waktu startingnya motor induksi tiga phasa, maka pemakaian energi listrik terus meningkat dimana pada rentang waktu 1 (satu) jam konsumsi energi listrik sebesar $0,428 \mathrm{kWh}$.

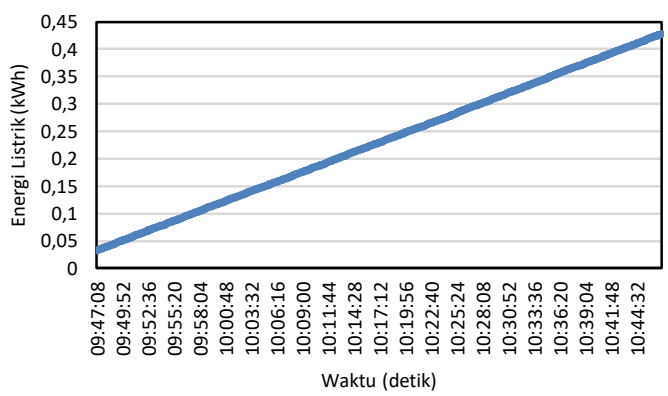

Gambar 18. Grafik pemakaian energi listrik motor induksi tiga phasa hubungan delta dengan kecepatan $3000 \mathrm{rpm}$ berbeban

Hasil pengukuran daya motor induksi tiga phasa hubungan delta berbeban berikutnya juga dilakukan dengan mengatur kecepatan motor induksi tiga phasa berbeban dengan kecepatan $2570 \mathrm{rpm}$ selama 1 jam, diperoleh bentuk grafik daya seperti pada gambar 19.

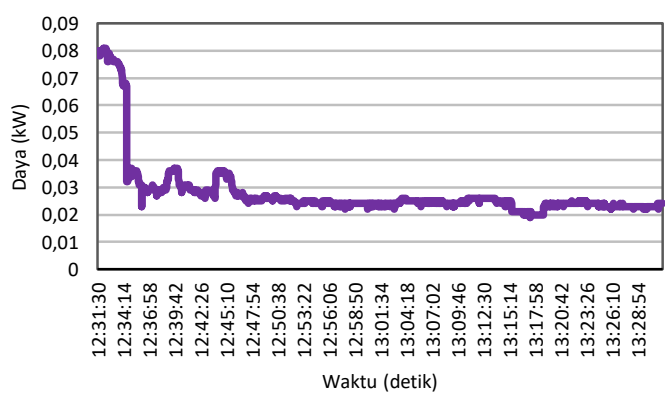

Gambar 19. Grafik daya motor induksi tiga phasa hubungan delta dengan kecepatan $2570 \mathrm{rpm}$ berbeban

Selanjutnya hubungan antara pemakaian energi listrik dari motor induksi tiga phasa hubungan delta berbeban pada kecepatan $2570 \mathrm{rpm}$ seperti pada gambar 20 dengan pemakaian energi listrik terus meningkat selama rentang waktu 1 (satu) jam dimana konsumsi energi listrik sebesar 0,979 kWh.

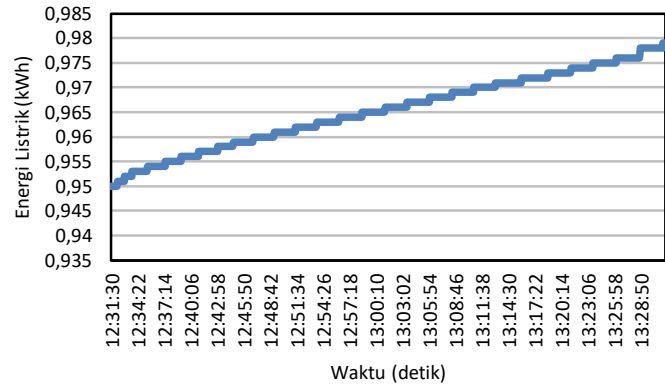

Gambar 20. Grafik pemakaian energi listrik motor induksi tiga phasa hubungan delta dengan kecepatan $2500 \mathrm{rpm}$ berbeban

Bentuk grafik perbandingan penggunaan energi listrik motor induksi tiga phasa hubungan delta berbeban dengan perubahan kecepatan seperti pada gambar 21.
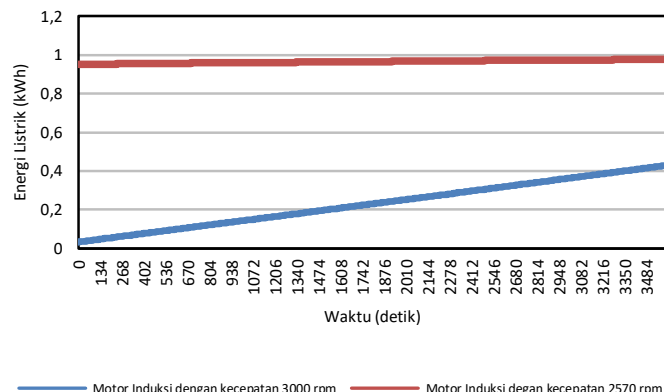

Gambar 21. Grafik perbandingan pemakaian energi listrik dengan perubahan kecepatan pada motor induksi tiga phasa hubungan delta berbeban.

Dari gambar 21 terlihat bahwa penggunaan energi listrik motor induksi tiga phasa hubungan delta berbeban dengan perubahan kecepatan dari awal starting sampai beroperasi dalam waktu 1 jam, penggunaan energi listrik motor induksi dengan kecepatan $2570 \mathrm{rpm}$ lebih tinggi sebesar $0,551 \mathrm{kWh}$ (56\%) dibandingkan dengan kecepatan motor induksi $3000 \mathrm{rpm}$.

Perbandingan penggunaan energi listrik dari motor induksi tiga phasa dengan perubahan kecepatan dari tiap hubungan motor dalam kondisi tanpa beban dan berbeban yang diperoleh dari tabel 1, tabel 2, tabel 3 dan 4 adalah seperti pada gambar 22 selama pemakaian satu (1) jam. 


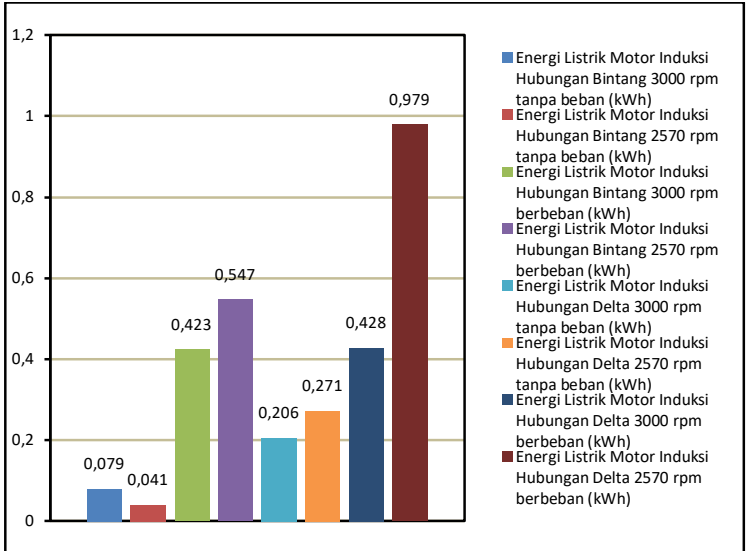

Gambar 22. Grafik perbandingan pemakaian energi listrik pada motor induksi tiga phasa dengan perubahan kecepatan

\section{KESIMPULAN}

1. Motor induksi tiga phasa hubungan bintang tanpa beban dengan kecepatan $3000 \mathrm{rpm}$ diperoleh konsumsi energi listrik sebesar $0,079 \mathrm{kWh}$, lebih tinggi sebesar 0,038 kWh (48\%) atau Rp. 51,376 selama satu jam bila dibandingkan dengan kecepatan $2570 \mathrm{rpm}$ dengan konsumsi energi listrik sebesar 0,041 kWh.

2. Motor induksi tiga phasa hubungan bintang berbeban dengan kecepatan $3000 \mathrm{rpm}$ diperoleh konsumsi energi listrik sebesar 0,423 kWh dan kecepatan $2570 \mathrm{rpm}$ diperoleh konsumsi energi listrik $0,547 \mathrm{kWh}$ dimana motor induksi tiga phasa kecepatan $2570 \mathrm{rpm}$ konsumsi energi listriknya lebih tinggi sebesar $0,124 \mathrm{kWh}(22 \%)$ atau Rp. 167,648 dalam satu jam bila dibandingkan dengan kecepatan $3000 \mathrm{rpm}$.

3. Motor induksi tiga phasa hubungan delta tanpa beban dengan kecepatan $3000 \mathrm{rpm}$ diperoleh konsumsi energi listrik sebesar 0,206 kWh dan saat kecepatan 2570 rpm konsumsi energi listrik $0,271 \mathrm{kWh}$ dimana konsumsi energi listrik motor induksi tiga phasa dengan kecepatan $2750 \mathrm{rpm}$ lebih tinggi sebesar $0,065 \mathrm{kWh}(23 \%)$ atau Rp. 87,88 dalam satu jam bila dibandingkan dengan kecepatan 3000 rpm.

4. Konsumsi energi listrik motor induksi tiga phasa hubungan delta berbeban dengan kecepatan 2570 rpm diperoleh sebesar $0,979 \mathrm{kWh}$, lebih tinggi sebesar 0,551 kWh (56\%) atau Rp. 744,952 dalam satu jam bila dibandingkan dengan kecepatan $3000 \mathrm{rpm}$ dengan konsumsi energi listrik sebesar $0,428 \mathrm{kWh}$.

\section{DAFTAR PUSTAKA}

[1] H. S. Sarhan, "Online energy efficient control of three-phase induction motor drive using PIC-microcontroller," Int. Rev. Model. Simulations, vol. 4, no. 5, pp. 2278-2284, 2011.

[2] G. Anindita, E. Setiawan, and A. Syahid, "Optimasi Energi pada Motor Induksi 3 Fasa dalam Memproduksi Kebutuhan Air (Studi Kasus di PDAM Karang Pilang Surabaya)," in Seminar Nasional Maritim, Sains dan Teknologi Terapan, 2016, vol. 01, no. November, pp. 87-94.

[3] Atmam, E. Zondra, and Zulvahri, "Analisis Penggunaan Energi Listrik Pada Motor Induksi Satu Phasa dengan Menggunakan Inverter," SainETIn, ISSN 2548-6888, vol. 1, no. 2, pp. 1-8; ISSN 2548-9445, 2017.

[4] L. Alberti, N. Bianchi, and S. Bolognani, "Finite element modeling of induction motor for variable speed drives," Electr. Mach. 2008. ICEM 2008. 18th Int. Conf., no. 2, pp. $1-5,2008$.

[5] H. Haryanto, "Pembuatan Modul Inverter sebagai Kendali Kecepatan Putaran Motor Induksi," J. Rekayasa, ISSN 0216-9495, vol. 4, no. 1, pp. 9-20, 2011.

[6] F. O. Enemuoh, E. E. Okafor, J. C. Onuegbu, and V. N. Agu, "Modelling, Simulation and Performance Analysis of A Variable Frequency Drive in Speed Control Of Induction Motor," Int. J. Eng. Invent., vol. 3, no. 5, pp. 36-41, 2013.

[7] Y. Liklikwatil, "Pengaturan Tegangan Kerja Minimum Motor Induksi Untuk Penghematan Pemakaian Energi Peralatan Yang Digerakan Oleh Motor Listrik," Isu Teknol. STT Mandala, vol. 5, no. 02, pp. 4757, 2013.

[8] S. K. Sen, Rotating Electrical Machinery 2nd Ed. 1987. 